\title{
DZIECIĘCA IKONOGRAFIA KSIĘŻNICZEK OKRESU AMARNEŃSKIEGO
}

\section{THE INFANT ICONOGRAPHY OF AMARNA PERIOD PRINCESSES}

\author{
Maria Monika Kloska \\ Instytut Archeologii. Uniwersytet im. Adama Mickiewicza w Poznaniu \\ ul. Umultowska 89D, 61-614 Poznań, Polska \\ Madame_16@poczta.fm
}

\begin{abstract}
This article explains the characteristic style of princesses representations in Amarna Period art. This high essential aspect (in literally way) shows full of love relations between family members from Akhetaten.

Children iconography in ancient Egypt remained rather persistent, however, pictures showing Meritaten, Maketaten, Ankhesenpaaten, Neferneferuaten, Neferneferure and Setepenre stand alone not only by details, but also by scenes in which princesses have been presented.

The royal daughters are often shown naked or in robes looking like delicate tied with sash in waist or under bust dress belonging to their mother Nefertiti. Though girls - regardless of age - have always been portrayed with the sidelock of youth.

The reliefs representing Amarna princesses and their parents deviate significantly from fixed and formal style of iconography which is characteristic for periods before and after Akhenaten's reigns. The girls have been shown not only in family scenes enjoying a good time with their parents, but also accompanying the royal couple in scenes of tribute from Nubia and Syria, in the scenes of killing enemies of Egypt and in the heart-touching mourning scenes.

The representations of the six daughters of Akhenaten and Nefertiti, besides being the symbol of the spouses' fertility, also performed an important religious function - the girls together with their parents and the god Aten created the divine Ennead just like the model of the nine gods from Heliopolis.

The reliefs showing Amarna family seem to present real feelings and emotions of the royal couple and their children, although it could have a propagandist character.
\end{abstract}

KEY WORDS: child in Ancient Egypt, children in Amarna Period, princesses in Amarna Period, art in Amarna Period, iconography in Amarna Period, Meritaten, Maketaten, Ankhesenpaaten, Neferneferuaten, Neferneferure, Setepenre, Neferneferuaten Nefertiti 
Dzieci w starożytnym Egipcie nie odgrywały ważniejszych funkcji zarówno w życiu publicznym, jak i religijnym, jednak posiadanie gromadki pociech było marzeniem każdego egipskiego małżeństwa, zarówno tego królewskiego, jak i normalnych śmiertelników. Dlaczego? Otóż, podobnie jak w dzisiejszych czasach, dzieci postrzegano jako źródło szczęścia i radości. Dodatkowo młodzi członkowie rodziny dawali swoim rodzicom poczucie bezpieczeństwa nie tylko na starość, ale i na wieczność, ponieważ dzięki potomkom mogły przetrwać zarówno ciała ${ }^{1}$ i imio$n^{2}$ rodzicieli, a co za tym idzie - zmarli mogli żyć wiecznie w zaświatach.

Zapewne takimi samymi uczuciami obdarzano wszystkie dzieci, jednak z narodzin chłopców cieszono się najbardziej, ponieważ to właśnie mężczyźni-kapłani odgrywali kluczową rolę podczas pogrzebu, jak i w kulcie zmarłych (Rachet, 1995, s. 92). Przykładowo najważniejszym rytuałem pogrzebowym była Ceremonia Otwarcia Ust ${ }^{3}$, której przewodził przyodziany w lamparcią skórę kapłan-sem w jego rolę wcielał się często syn nieboszczyka lub jego dziedzic. Co bardzo istotne, przytoczona ceremonia uzmysławia, że synowie byli bardziej cenieni we wszystkich kręgach społecznych, to znaczy zarówno normalnemu człowiekowi, jak i faraonowi bardziej zależało na męskim potomku, ponieważ, czy to królewski syn, czy nie, miał on do spełnienia te same obowiązki wobec swoich rodziców/opiekunów.

Sceny ukazujące życie rodzinne są jednymi z najbardziej osobliwych przedstawień Okresu Amarneńskiego. Zabytki z czasów rządów Achenatona i Nefertiti są jedynymi w egipskiej historii, które w piękny oraz, jak na starożytny Egipt, dosłowny sposób prezentują miłość małżonków, miłość rodziców wobec dzieci, dzieci wobec rodziców oraz uczucia i relacje między nimi. Przedstawienia amarneńskich księżniczek: Meritaton, Maketaton, Anchesenpaaton, Neferneferuaton, Neferneferure i Setepenre są bardzo charakterystyczne, przez co warte analizy i omówienia. Siostry występują na różnych rodzajach reliefów, również w typach scen, w których dotychczas dzieci nie ukazywano, jak na przykład zabijanie wrogów Egiptu.

\footnotetext{
${ }^{1}$ Zadbanie o przetrwanie ciała człowieka w idealnym stanie po jego śmierci było jednym z najistotniejszych zadań, jakie stawiali sobie Egipcjanie jeszcze za życia. Otóż ciało (eg. chet) było gwarantem życia w zaświatach, ponieważ zarówno dusza $k a$, jak i $b a$ musiały co jakiś czas jednoczyć się z mumią zmarłego (eg. sah), aby móc egzystować. Podejrzewa się, że to właśnie obowiązek zachowania zwłok (eg. chat) w idealnym stanie spoczywa u podstaw narodzin mumifikacji (więcej na ten temat: Ikram, 2003, s. 24).

${ }^{2}$ Imię (eg. ren) uważano za jeden z pryncypialnych elementów składowych człowieka. Nadawało tożsamość zarówno za życia na ziemi, jak i w zaświatach, a bez niego dana osoba nie mogła istnieć. $\mathrm{Z}$ tych względów Egipcjanie bardzo dbali, aby ich imiona przetrwały nawet po śmierci. Zapisywano je więc w grobowcu, jak i na darach grobowych (więcej na ten temat: Ikram, 2003, s. 24-25). Z zatarciem imienia ściśle wiąże się procedura damnatio memoriae, czyli potępienie pamięci. Otóż w starożytnym Egipcie był to najstraszniejszy akt, jaki można było zastosować wobec danego człowieka, ponieważ według wierzeń wraz z wymazaniem imienia człowieka unicestwiano go nawet w zaświatach. Tego typu kroki podjęto wobec Achenatona i Nefertiti.

${ }^{3}$ Eg. upet- $r$, akt ten niejako otwierat mumię - przywracał jej wszystkie zmysły żywego człowieka, zaś zmarły mógł się przekształcić w ach, który możemy określić mianem ducha lub bytu astralnego (więcej na ten temat: Ikram, 2003, s. 29-31, 151-152).
} 
Nefertiti być może urodziła Achenatonowi oprócz sześciu córeczek również dwóch chłopców: Semenchkare i syna Tutanchatona ${ }^{4}$. Jednak mimo faktu, że to narodziny synów były bardziej wyczekiwane, młodzi książęta występują w egipskiej ikonografii bardzo rzadko. Tak samo jest w przypadku Okresu Amarneńskiego. Otóż para królewska bardzo często przedstawiana była właśnie z księżniczkami, a nigdy z księciem ${ }^{5}$. Rodziców Achenatona, Amenhotepa III i Teje również pokazywano wyłącznie z córkami, mimo że mieli dwóch synów: starszego - przedwcześnie zmarłego - Totmesa oraz młodszego - Amenhotepa, czyli późniejszego króla Egiptu Achenatona. O istnieniu młodego księcia właściwie się nie wspomina, a jego imię pojawia się tylko raz na pieczęci z dzbana na wino odkrytego w Malgatta ${ }^{6}$. Tajemnicze dzieciństwo Achenatona, jak i Tutanchamona czy Semenchkare nie powinno być niczym zaskakującym, ponieważ książęta po prostu nie brały udziału w życiu publicznym rodziny królewskiej, zarówno w tym publicznym, jak i religijnym czy kultowym. Dzieci wychowywano w zaciszu pałacu królewskiego i jedynie księżniczki towarzyszą swoim ojcom i matkom w różnych ceremoniach.

\section{ZAPIS HIEROGLIFICZNY A POSTAĆ DZIECKA W IKONOGRAFII}

Już sam hieroglif ukazujący dziecko prezentuje, w jaki sposób postrzegano małego człowieka i jak przedstawiano go w ikonografii. Otóż słowo dziecko można

zapisać hieroglifami w różnoraki sposób. Znak (A17) ${ }^{7}$ oraz jego warianty
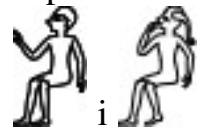

przedstawiają siedzące dziecko, które w charakterystyczny sposób jedną dłonią dotyka ust (poza jednym wariantem) i w niektórych przypadkach ma na głowie tak zwany lok młodości. Znak ten jest determinatywem słowa młody i sta-

\footnotetext{
${ }^{4}$ Kwestia ta cały czas wzbudza wiele kontrowersji. Najwięcej dyskusji dotyczy matki Tutanchatona, ponieważ część badaczy uważa, że była nią Kija, a część, że Nefertiti. Najnowsze badania DNA mumii datowanych na czasy Amarny, jakie przeprowadził Zahi Hawass wraz z zespołem (Hawass, 2010, s. 638-647), skłaniają autorkę tegoż artykułu ku przekonaniu, że matką Tutanchatona była Nefertiti. Kwestia ta zostanie bliżej omówiona i przeanalizowana w pracy doktorskiej autorki. Ciekawym artykułem na ten temat jest: Gabolde, 2013, s. 177-203. Natomiast teorii związanych z postacią Semenchkare jest wiele - część egiptologów uważa, że tego enigmatycznego władcę należy utożsamiać z najstarszym synem Achenatona (Kemp, 2013, s. 15), według innych był on synem Amenhotepa III i Teje, a zatem bratem Achenatona (Allen, 2007, s. 13-14), zaś według M. Gabolda w rolę Semenchkare wcielił się książę Zannanza (Gabolde, 1998, s. 213-226).

${ }^{5}$ Jedynym znanym, choć wzbudzającym wiele kontrowersji reliefem, który prawdopodobnie ukazuje małego Tutanchatona, jest przedstawienie z Grobowca Królewskiego w Achetaton (ryc. 8 i 10).

${ }^{6}$ Więcej na ten temat: Redford, 1987, s. 58-59.

${ }^{7} \mathrm{~W}$ niniejszej pracy wszelkie hieroglify oznaczane są według Listy Znaków Alana Gardinera, znajdującej się w: Gardiner, 1957.
} 
nowi składowy element słów oznaczających dziecko:
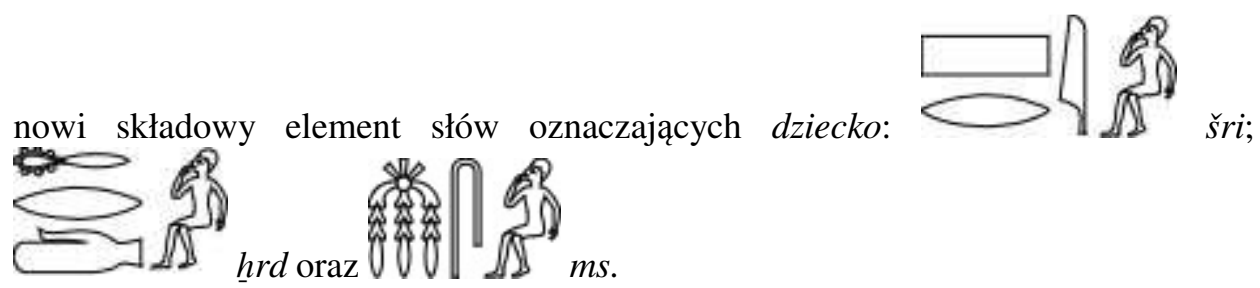

Warto zaznaczyć, że w związku z wysoką umieralnością dzieci w starożytnym Egipcie oraz faktem, że nie spełniały one ważniejszych ról w życiu publicznym, artyści ukazywali je stosunkowo rzadko. Jeżeli już przedstawiano dzieci na reliefach czy w rzeźbie, robiono to w dwojaki sposób albo ukazywano je jako niemowlaki nagie z palcem w buzi oraz lokiem młodości na głowie, co pokazują chociażby znaki hieroglificzne, lub jako miniaturowych dorosłych (Feucht, 2001, s. 262).

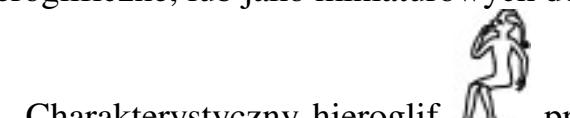

Charakterystyczny hieroglif $\Omega$ przedstawia dziecko w owym specyficznym uczesaniu zwanym lokiem młodości. Zarówno dziewczynki, jak i chłopcy nosili nad prawym uchem zapleciony w warkoczyk kosmyk włosów, podczas gdy reszta głowy pozostawała dokładnie ogolona. $\mathrm{W}$ inskrypcjach spotkać można hieroglif prezentu-

jący sam lok młodości 6 , który był stosowany jako determinatyw w słowach, które łączyły się z dziećmi i dzieciństwem (Guillemette, 2012, s. 154). Warkoczyk noszą również bóstwa przybierające formę dziecka, na przykład syn Izydy i Ozyrysa - Horus ${ }^{8}$, Chonsu' ${ }^{9}$, będący synem Amona i Mut, oraz tak zwane Dziecko Stońca, czyli Nefertum $^{10}$, który z kolei jest synem Sachmet i Ptaha.

Przez cały okres trwania starożytnego Egiptu ikonografia dziecka pozostaje raczej niezmienna. Choć jak zauważymy w dalszej części pracy, przedstawienia amarneńskich księżniczek można uznać za wyjątkowe pod kilkoma względami. Otóż ikonografię amarneńskich córek wyróżniają nie tylko detale, ale i sceny, w jakich księżniczki były ukazywane.

Co istotne, dziewczynki i chłopcy przedstawiani byli bez szat, ale często z biżuterią: naszyjnikami, amuletami, talizmanami, bransoletami, których zadaniem było odpędzanie złych mocy i sprowadzanie szczęścia (Aldred, 1978, s. 10).

Czy dzieci w prawdziwym życiu również na co dzień biegały gołe? Przyjmuje się, że wraz z osiągnięciem dojrzałości płciowej młodzi ludzie przyodziewali szaty.

\footnotetext{
${ }^{8}$ Np.: Brooklyn Museum 37.1095E, https://www.brooklynmuseum.org/opencollection/objects/4120 [dostęp: 12 IX 2017].

${ }^{9}$ Np.: MMA 89.2.525, https://www.metmuseum.org/art/collection/search/570650 [dostęp: 12 IX 2017].

${ }^{10}$ Słynnym przedstawieniem nawiązującym do Nefertuma jest odkryta w grobowcu KV62 dziecięca główka o rysach twarzy Tutanchamona wyłaniająca się z kwiatu lotosu JE 60723, http://www.griffith. ox.ac.uk/gri/carter/008.html [dostęp: 12 IX 2017].
} 
Aczkolwiek znane są przedstawienia zupełnie nagich młodych dziewcząt o wyraźnie kobiecych kształtach, które spędzają czas na zabawie z równie nagimi chłopcami (Guillemette, 2012, s. 153). Zdaje się zatem, że nagość młodych osób być może stanowiła kanon artystyczny, którego zadaniem było bezproblemowe odróżnienie osób dorosłych od dzieci i podlotków. Jeżeli zaś spojrzymy na tę kwestię z czysto praktycznej perspektywy, zauważymy również, że noce nad Nilem, zwłaszcza w porze zimowej, są bardzo chłodne, więc podobnie jak i dziś rodzice na pewno dbali, aby ich pociechy nie zmarzły i nie chorowały, więc przynajmniej po zachodzie słońca dzieci prawdopodobnie nie chodziły nagie ${ }^{11}$.

\section{AMARNEŃSKIE KSIĘŻNICZKI - DETALE PRZEDSTAWIEŃ}

Amarneńskie córy stanowiły symbol płodności swoich rodziców oraz pełniły ważną funkcję religijną. Otóż dziewczynki wraz z Achenatonem i Nefertiti oraz bogiem Atonem tworzyły boską Eneadę na wzór tej z Heliopolis (Reeves, 2001, s. 146). Faraon był odpowiednikiem boga Szu, królowa sprawowała rolę bogini Tefnut, zaś Aton pełnił funkcję boga Atuma, natomiast siostry pozostałych sześciu bogów: Geba i Nut, Ozyrysa i Izydy, Setha i Neftydy.

Jednak w związku z powyższym w amarneńskich inskrypcjach dotyczących księżniczek nie znajdziemy nawiązań do owych bóstw. Tytulatura dziewczynek przez cały okres panowania ich ojca nie ulegała większym zmianom ${ }^{12}$. Siostry określane były następującą frazą: s3.t nswt $n(. t)$ ht.f $m$ r.t.f [imię księżniczki] $m s . t n$ hm.t nswt wr.t (Nfr-nfr.w-itn Nfr.t-ii.ti)|, co przetłumaczymy ${ }^{13}$ : |Córka Króla z Jego Ciała, Jego Ukochana [imię księżniczki], zrodzona z Wielkiej Mał̇̇onki Króla (Neferneferuaton-Nefertiti)| $\left.\right|^{14}$. Wszelkie wariacje, jakie możemy napotkać, dotyczą tylko zawartych w tytularze dziewczynek epitetów ich matki Nefertiti.

Funkcja, jaką odgrywały księżniczki, spowodowała, że obowiązkowo włączono je do kanonu przedstawień rodzinnych. W stosunku do swoich ciotek, czyli sióstr

\footnotetext{
${ }^{11}$ Wskazują na to również odkrycia archeologiczne dziecięcych ubranek znad Nilu (więcej na ten temat: Guillemette, 2012, s. 154).

${ }^{12}$ Fraza, jaką określano trzy najstarsze księżniczki, których imiona pojawiają się na talatat pochodzących ze świątyń Atona w Karnaku, nie różni się od ich tytulatury zapisywanej w Achetaton oraz od tytulatury młodszych sióstr, które narodziły się już w nowej stolicy.

${ }^{13}$ Tłumaczenia imion i zwrotów egipskich na język polski, które nie mają odnośników do literatury, zostały dokonane przez autorkę.

${ }^{14} \mathrm{~Np} .:$ Tytulatura znajduje się m.in. na płycie z ołtarza z Achetaton ÄM 14145, http://www.smbdigital.de/eMuseumPlus?service=direct/1/ResultLightboxView/result.t1.collection_lightbox.\$TspTitleI mageLink.link\&sp=10\&sp=Scollection\&sp=SfieldValue \&sp=0\&sp=0\&sp=3\&sp=Slightbox_3x4\&sp= $0 \& \mathrm{sp}=$ Sdetail $\& \mathrm{sp}=0 \& \mathrm{sp}=\mathrm{F} \& \mathrm{sp}=\mathrm{T} \& \mathrm{sp}=1$ [dostęp: 12 IX 2017].
} 
Achenatona $^{15}$, księżniczki występują niezwykle często na amarneńskich reliefach. Warto także zaznaczyć, że sposób, w jaki przedstawiano księżniczki z Achetaton, znacznie różni się od tego, jak ukazywano królewskie córy w przeddzień rewolucji religijnej ${ }^{16}$. Otóż córki królowej Teje praktycznie nigdy nie są ukazywane jako małe i nagie dzieci z lokami młodości na głowach, lecz jako młode dziewczęta. Zaś amarneńskie siostry ukazywane są jako małe kopie swojej matki lub po prostu jako małe i nagie dzieci. Królewscy artyści ukazywali je w bardzo zindywidualizowany sposób - w zależności od wieku różnie się zachowują, razem z rodzicami występują w innych scenach, a zmieniające się detale fryzury, takie jak długość loku młodości, wskazują na upływ czasu. Aczkolwiek wydaje się, że dziewczynki mimo osiągnięcia nastoletniego wieku cały czas ukazywane były jako symbol płodności pary królewskiej, czyli jako małe dzieci.

\section{Szaty księżniczek i ich nagie przedstawienia}

Tak jak już zaznaczono, księżniczki często wyglądają jak ich matka (ryc. 1), więc warto przeanalizować pokrótce, w jaki sposób ukazywano Nefertiti. Otóż według kanonu sztuki amarneńskiej władczyni otrzymała szerokie biodra, grube uda i krągłe pośladki, które zapewne wskazywały płodność i fakt urodzenia sześciorga córeczek (książąt?). Nefertiti zachowała jednak wąską talię. W związku z tym, że obfite piersi nie charakteryzowały wyłącznie kobiet, nie podkreślano ich w szczególny sposób u królowej. Nefertiti przedstawiano najczęściej w delikatnej, wręcz przezroczystej sukni przewiązanej szarfą w pasie lub pod biustem. Często owa suknia całkowicie odsłaniała nagie ciało, ponieważ pozostawiano ją otwartą z przodu. Jak zauważymy na załączonym przerysie reliefu z grobowca dostojnika Api, Meritaton, Maketaton i Anchesenpaaton wyglądają identycznie jak ich rodzicielka. Dziewczynki odróżniają od matki wyłącznie nakrycia głów, a właściwie ich brak, ponieważ księżniczki ukazano z lokiem młodości, zaś królową najczęściej w jej charakterystycznej prosto ściętej Btękitnej Koronie.

Trzy najstarsze księżniczki, Meritaton, Maketaton i Anchesenpaaton, narodziły się jeszcze w Tebach przed 6. rokiem panowania ich ojca, czyli przed przeniesieniem się rodziny królewskiej do Achetaton. Możemy przyjąć takie założenie, ponieważ siostry występują razem na tebańskich reliefach, równie pomocne okazują się analizy stel granicznych nowej stolicy.

${ }^{15}$ Córki Amenhotepa III i Teje oraz jednocześnie siostry Achenatona to: Satamon, Henuttaneb, Aset, Nebetah oraz Baketaton.

${ }^{16}$ Zabytki, na których możemy zobaczyć córki Amenhotepa III to między innymi: tron Teje (CG 51112), tron Satamon (CG 51113) oraz reliefy z grobowców Cheruefa oraz Hui, dwie plakietki z karneolu (MMA 26.7.1339, MMA 44.2.1) oraz kolosy z Medinet Habu (JE 33906). 


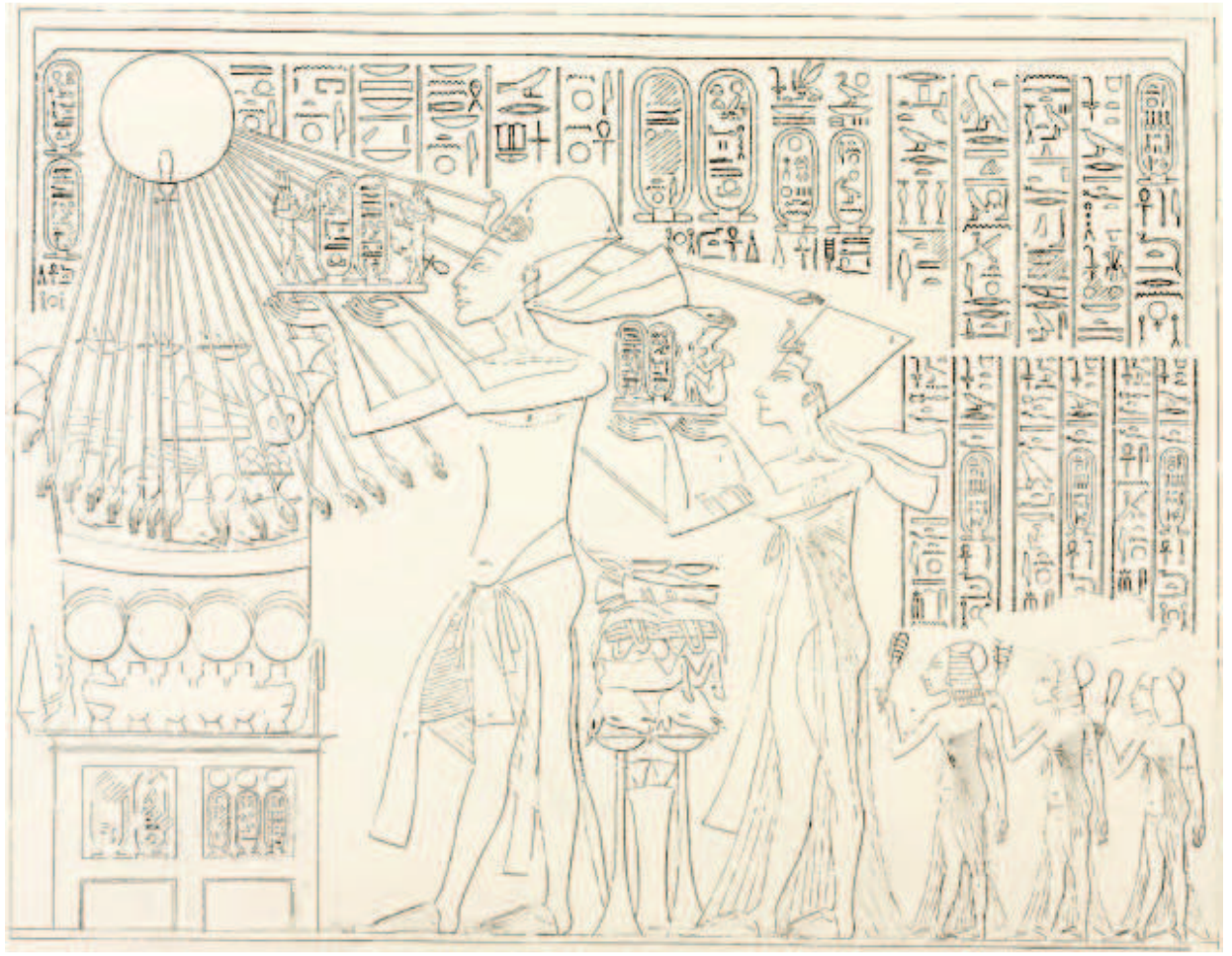

Ryc. 1. Relief z grobowca Api. Achetaton (Davies, 1908, T. 4, pl. XXXI).

Fig. 1. The fragment of a relief in the Tomb of Apy (Davies 1908, T. IV, pl. XXXI)

Przedstawienia księżniczek z Karnaku są oczywiście najwcześniejsze, a najczęściej ukazywaną księżniczką jest najstarsza - Meritaton. Dziewczynka odgrywała ważną rolę na królewskim dworze już od najmłodszych lat. Analizując zabytki, na których przedstawiona została wraz z rodziną, zauważymy, że dziewczynka występuje najbliżej ojca ${ }^{17}$ lub stoi tuż za rodzicami ${ }^{18}$, co świadczy o jej wysokiej pozycji, jako najstarszej córki. W świątyniach zadedykowanych Atonowi, które Achenaton nakazał wybudować w Karnaku, księżniczka była przedstawiana wraz z rodzicami podczas oddawania czci Atonowi lub podczas składania ofiar. Na rekonstrukcjach pylonu z Hut-Benben (ryc. 2) oraz Kolumnady Nefertiti (ryc. 3) widzimy Meritaton z lokiem młodości na głowie oraz w sukni identycznej, w jaką przyodziana jest jej matka. Księżniczkę uwieczniono w sposób typowy dla egipskiej Wielkiej Matżonki

${ }^{17}$ Np.: Płyta z ołtarza z Achetaton, ÄM 14145, http://www.smb-digital.de/eMuseumPlus?service $=$ direct $/ 1 /$ ResultLightboxView/result.t1.collection_lightbox.\$TspTitleImageLink.link\&sp=10\&sp=Scoll

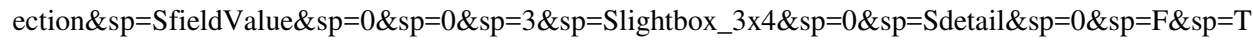
$\& \mathrm{sp}=1$ [dostęp: 12 IX 2017].

${ }^{18}$ Np.: Fragment balustrady z Achetaton (Cairo 30/10/26/12; Reeves, 2001, s. 150). 
Króla, która asystuje faraonowi-kapłanowi podczas religijnej ceremonii. Te wczesne wizerunki Meritaton odzwierciedlają główny kanon przedstawień księżniczek, jaki występuje w Karnaku ${ }^{19}$.

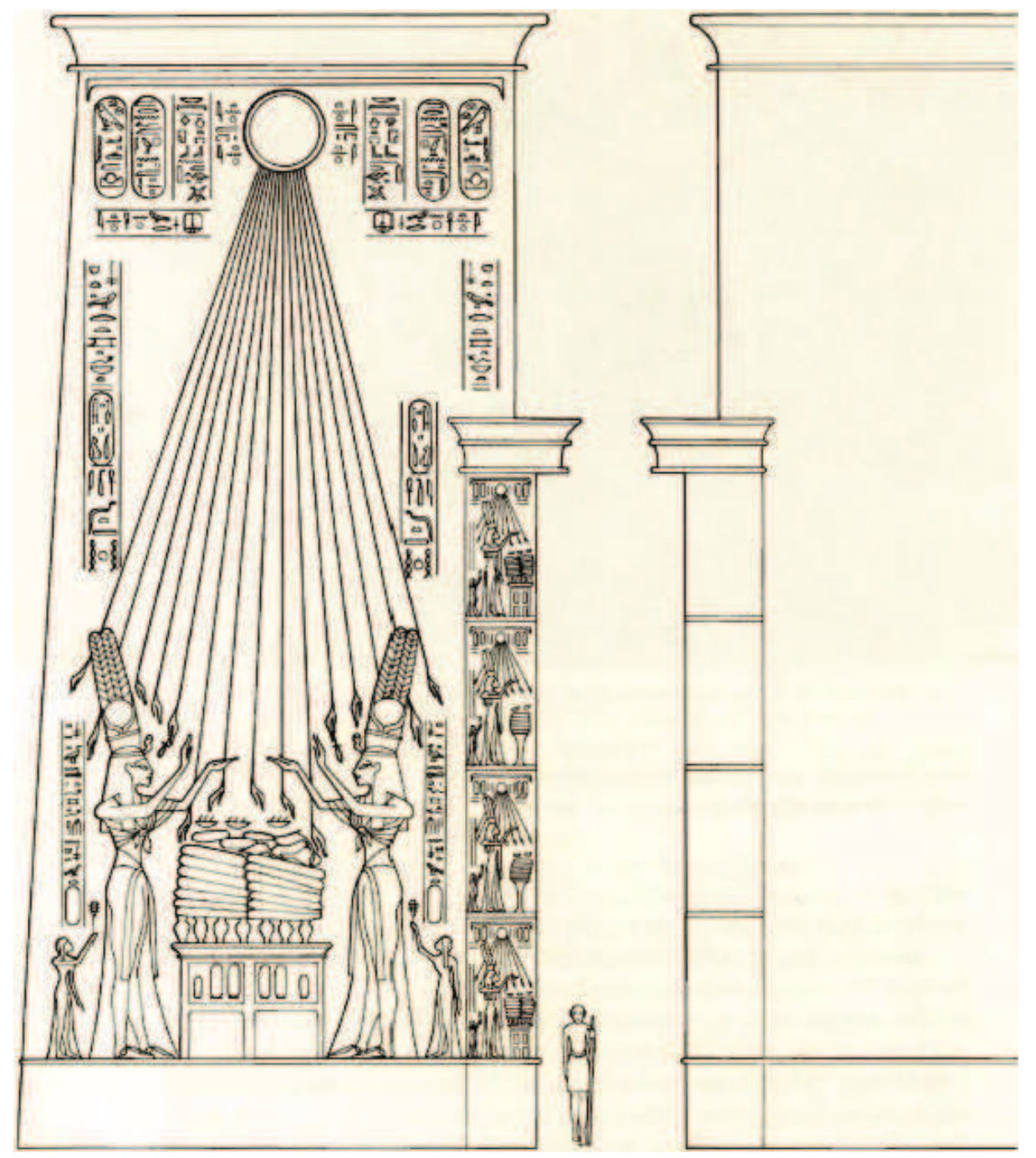

Ryc. 2. Fragment rekonstrukcji pylonu z Hut-Benben (Redford, 1976, s. 76)

Fig. 2. The reconstruction of the pylon from Hut-Benben (Redford, 1976, p. 76)

${ }^{19}$ Np.: D. B. Redford, R. W. Smith, The Akhenaten Temple Project, Initial Discoveries (T. 1), Warminster 1976, pl. XXII, XXVIII-XXIX, XXXI, XXXIII: 1 oraz przedstawienia Meritaton wraz Maketaton, pl. XXX, XXXII: 2, XXXII: 7, XXXIII: 5. 


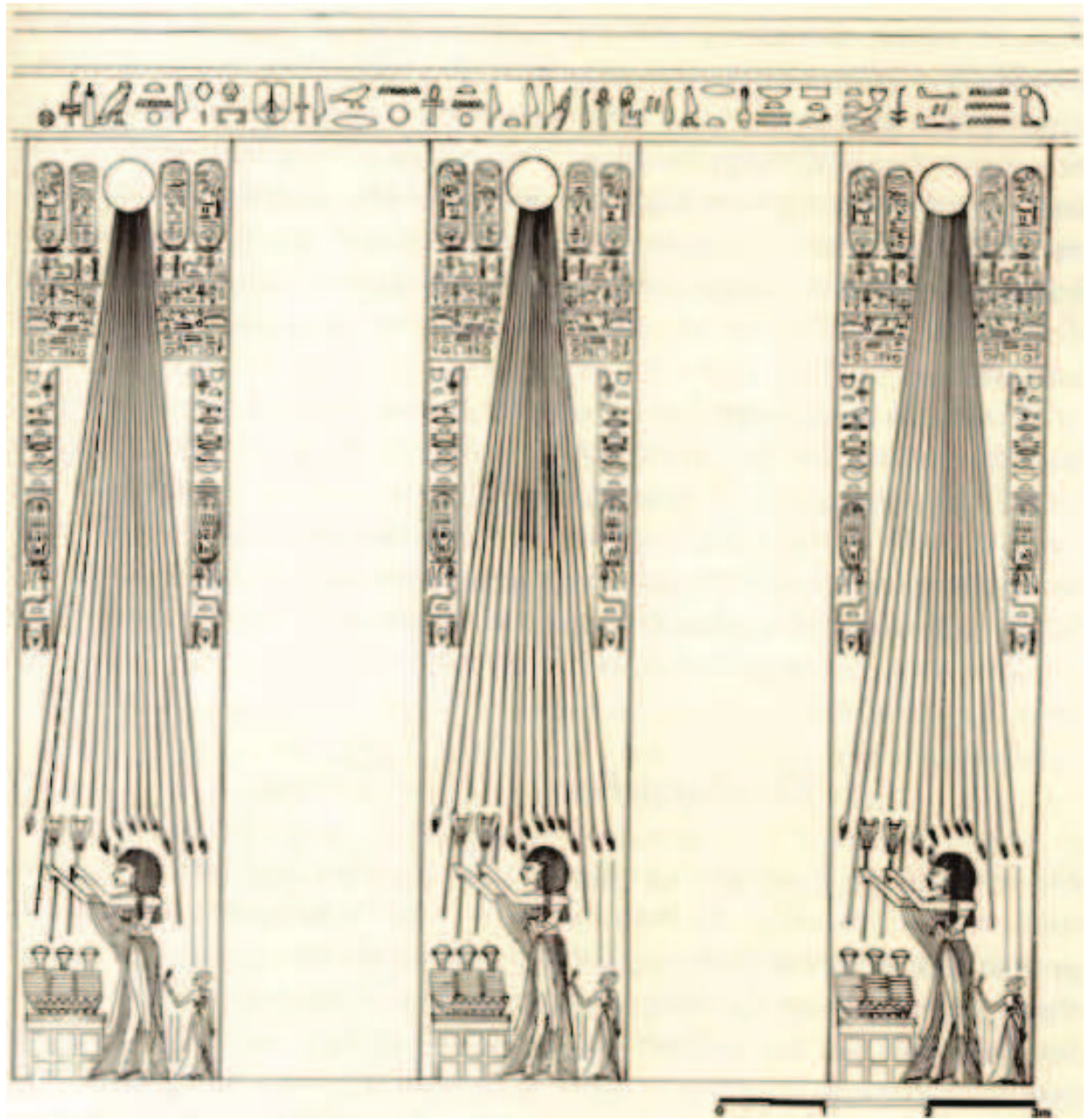

Ryc. 3. Fragment rekonstrukcji Kolumnady Nefertiti (Redford, 1976, s. 77)

Fig. 3. The fragment of the reconstruction of the Nefertiti's Colonnade (Redford, 1976, p. 77)

Po przeniesieniu się do nowej stolicy dziewczynki również noszą szatę matki (ryc. 1) lub przedstawiane są nagie ${ }^{20}$. Ciekawym i dobrze zachowanym zabytkiem ukazującym trzy najstarsze dziewczynki jako małe i gołe postacie jest słynna stela ÄM 14145 przechowywana w Nueus Museum w Berlinie. Relief ukazuje siedzącą na tronach parę królewską wraz z Meritaton, którą trzyma w ramionach Achenaton oraz z Maketaton i Anchesenpaaton, które towarzyszą władczyni. Nad amarneńską rodziną pieczę sprawuje bóg Aton.

\footnotetext{
${ }^{20}$ Np.: Stela domowa z Achetaton. Berlin ÄM 14145.
} 
Istnieje tylko jedno przedstawienie amarneńskiej córy w krótkiej spódniczce, które odkryto na wieku pudełeczka z grobowca Tutanchamona ${ }^{21}$ (ryc. 4). Jest to mała Neferura ubrana w kilt, mająca na głowie nubijski lok młodości. W bardzo podobnych sukniach, dłuższych i krótszych, odsłaniających nagi tułów, ukazywano ciotki małej Neferure, czyli Satamon i Henuttaneb. Przykłady tego typu tradycyjnych szat znajdziemy na tronie Teje (CG 51112 - Davies, Mapsero, Newberry, 1907, s. 43) oraz tronie Satamon (CG 51113 - Davies, Mapsero, Newberry, 1907, s. 38).

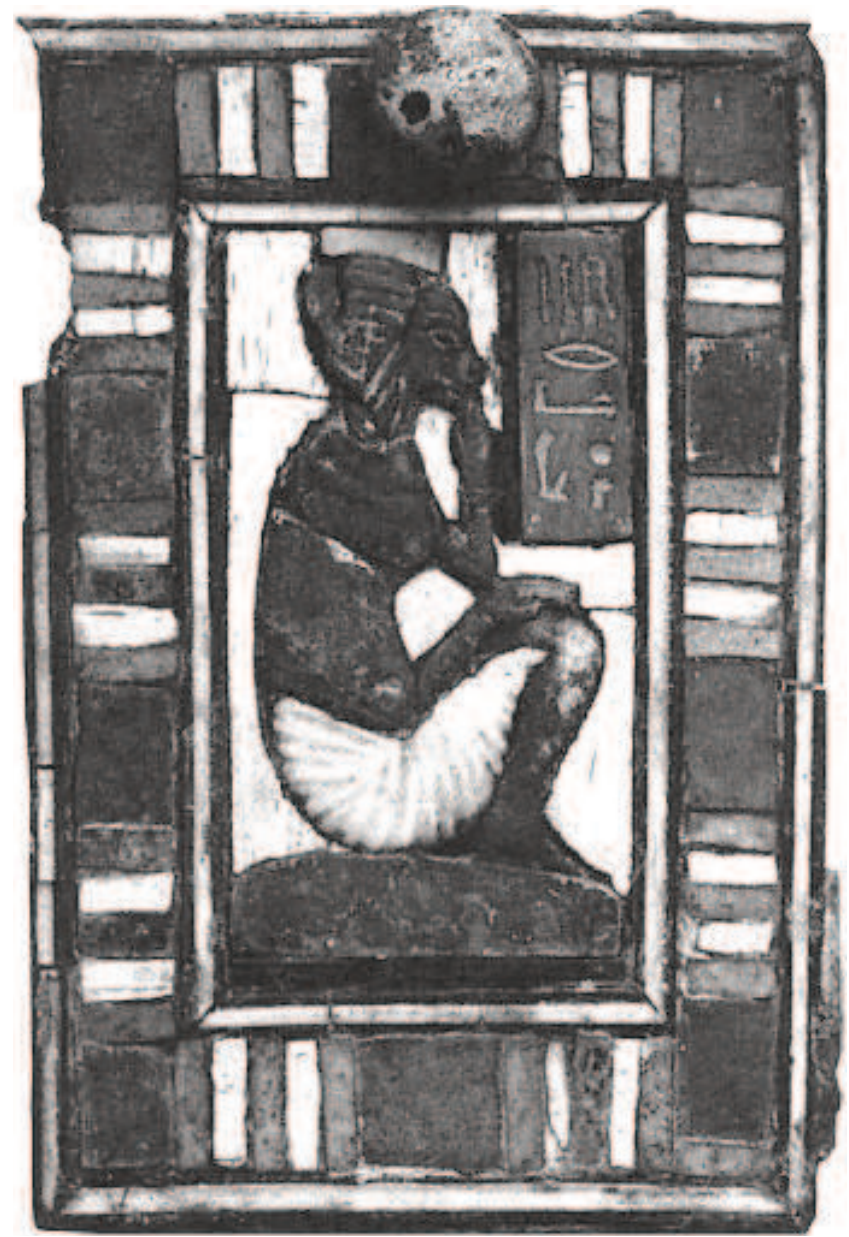

Ryc. 4. Wieko pudełeczka z grobowca Tutanchamona, http://www.griffith.ox.ac.uk/gri/carter/054hh.html [dostęp: 26 I 2017]

Fig. 4. The lid of the box from Tutankhamun's tomb, http://www.griffith.ox.ac.uk/gri/carter/054hh.html [dostęp: 26 I 2017 r.]

\footnotetext{
${ }^{21}$ Patrz: http://www.griffith.ox.ac.uk/gri/carter/054hh.html [dostęp: 12 IX 2017].
} 


\section{Fryzury księżniczek}

Kolejnym bardzo istotnym elementem w ikonografii księżniczek jest ufryzowanie, w którym można dostrzec kilka zmian. Jeżeli przeanalizujemy wygląd główek córek Achenatona i Nefertiti, zauważymy, że lok młodości może przybierać różne formy. W grobowcach Meryre I oraz Panehesi (ryc. 5) znajdują się reliefy ukazujące parę królewską na rydwanach (Davies, 1907, T. 2, pl. XV). Na przedstawieniach widoczne są również księżniczki powożące własnymi powozami. Dziewczynki mają na głowach klasyczny lok młodości oraz zmodyfikowaną jego wersję, którą możemy nazwać nubijskim lokiem młodości, ponieważ przypomina część tej peruki. W grobowcu Meryre II w scenach wręczania złota oraz w scenie składania trybutu przez Nubijczyków i Syryjczyków (ryc. 6) możemy zobaczyć najstarszą z sióstr, Meritaton, która ma na głowie bardzo długi, opadającym na plecy, lok młodości (Davies, 1907, T. 2, pl. XXXIII).

Analizując detale ikonograficzne charakterystyczne dla księżniczek amarneńskich, przede wszystkim zauważymy, jak wielki wpływ na ich ikonografię wywarł kanon przedstawień Nefertiti. Możemy jedynie snuć domysły, że królowa osobiście nadzorowała styl, w jakim uwieczniano w reliefie jej córki. Warto tu przytoczyć

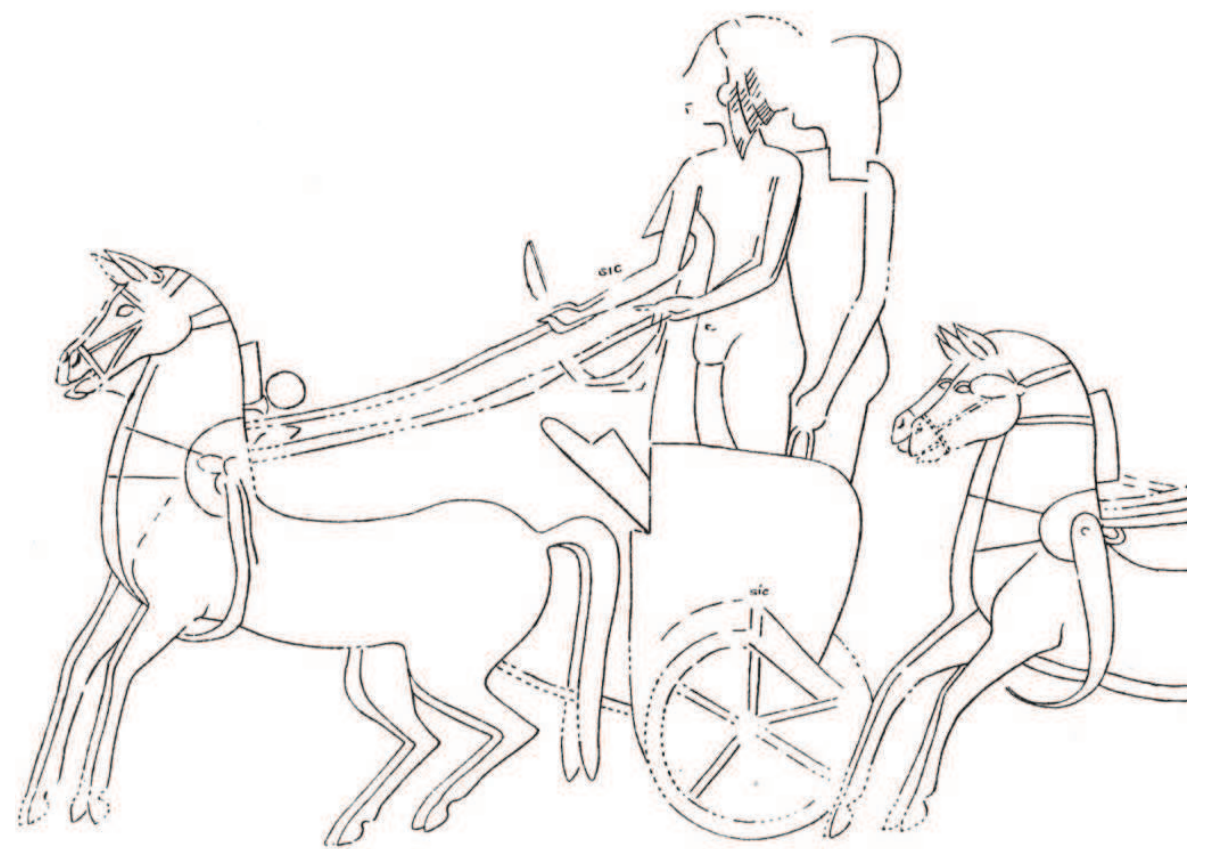

Ryc. 5. Przerys ukazujący dwie księżniczki powożące rydwanem. Grobowiec Panehesi (Davies, 1905, T. 2, pl. XV)

Fig. 5. The outline of two princesses driving the chariot. The Tomb of Panehesy (Davies, 1905, T. 2, pl. XV) 


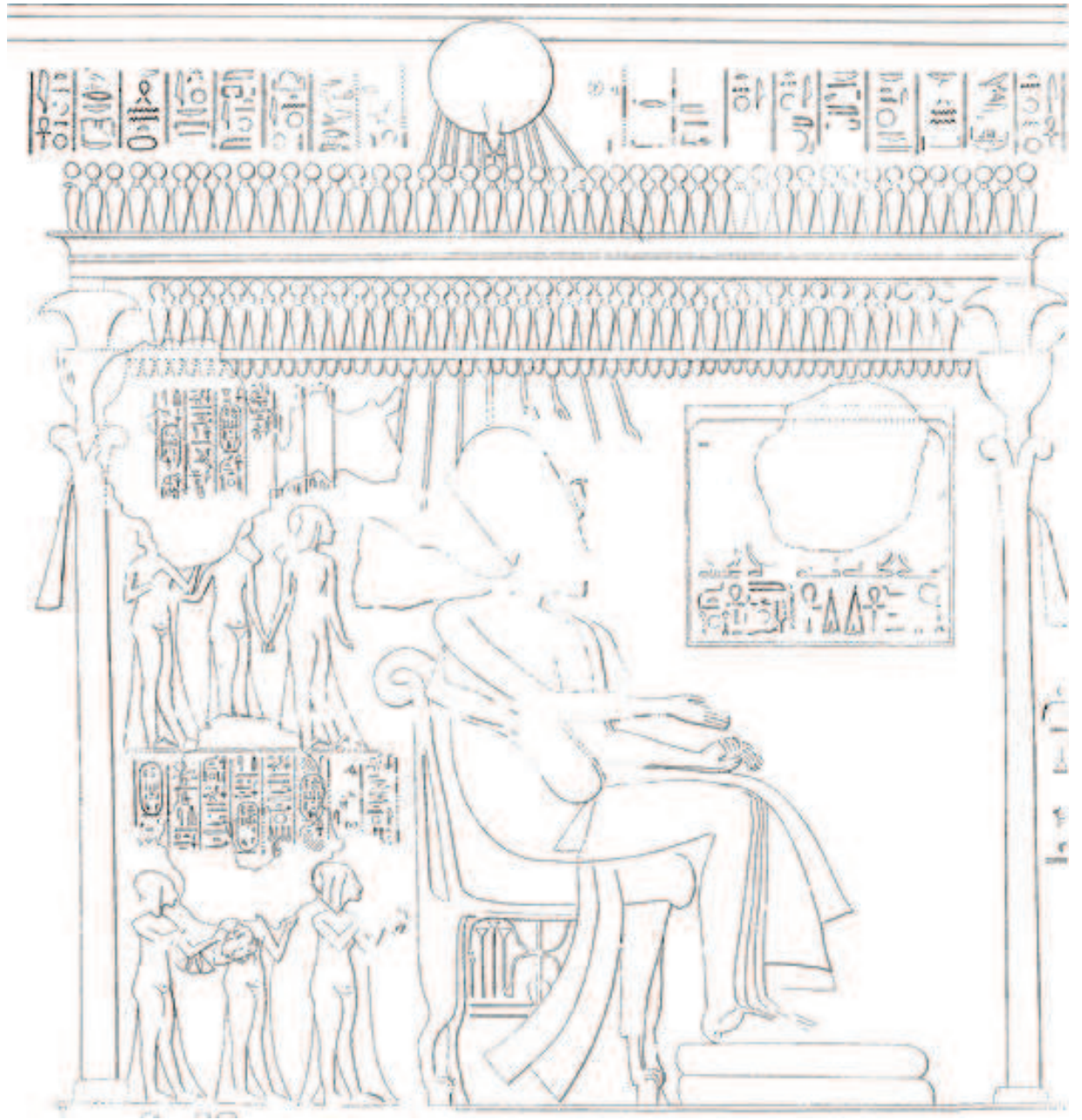

Ryc. 6. Przyjmowanie trybutu od Nubii i Syrii. Fragment reliefu z grobowca Meryre II. Achetaton (Davies, 1905, T. 2, pl. XXXVII, XXXVIII)

Fig. 6. The receiving scene of the tribute from Nubia and Syria. The fragment of a relief in the Tomb of Meryre II (Davies, 1905, T. II, pl. XXXVII, XXXVIII)

wspomniane już siostry Achenatona. Otóż również one były ukazywane w sposób analogiczny do kanonu charakterystycznego dla Teje. Siostry, wyłączając Baketaton ${ }^{22}$,

${ }^{22} \mathrm{~W}$ amarneńskim grobowcu dostojnika Hui znajdują się reliefy, na których ukazano królową Teje razem z najmłodszą z córek, Baketaton (Davies, 1905, T. 3, pl. IV, VI, XVIII). Ikonografia księżniczki znacznie odbiega od kanonu jej starszych sióstr. Otóż Baketaton przedstawiana jest w stylu typowym dla amarneńskich księżniczek. Na przedstawieniach ma na głowie lok młodości oraz ubrana jest w charakterystyczną dla Nefertiti zwiewną fałdowaną suknię. Księżniczka, mimo że była córką Amenhotepa III 
noszą tradycyjne suknie i nakrycia głowy bardzo podobne do tych noszonych przez ich matkę. Zaś najstarsza z sióstr, Satamon, podobnie jak później Meritaton, bywała wyróżniana w szczególny sposób - ukazywano ją w scenach stricte nawiązujących do reliefów ukazujących Teje lub stała najbliżej rodziców. Dzięki analizie przedstawień Satamon, Henuttaneb, Aset i Nebetah widoczne stają się modne w czasach rządów Amenhotepa III nakrycia głowy, suknie czy artefakty trzymane w dłoniach ${ }^{23}$. W ikonografii amarneńskich księżniczek nie uświadczymy kwiecistego diademu, modiusu, tradycyjnych przylegających do ciała sukni czy naszyjnika menat, ponieważ również Nefertiti nie jest ukazywana $\mathrm{z}$ tego typu artefaktami. Wydaje się zatem, że styl przedstawień księżniczek był oparty na kanwie reliefów i rzeźb ich matek ${ }^{24}$.

\section{AMARNEŃSKIE KSIĘŻNICZKI - RODZAJE SCEN}

Od czasów Starego Państwa wszelkie relacje między członkami rodziny królewskiej przedstawiano z dużą ostrożnością i powściągliwością. Faraona ukazywano wraz z małżonką ${ }^{25}$ lub małżonką i dziećmi ${ }^{26}$, zawsze w sztywnych i formalnych pozach. Aczkolwiek dzieci wychowywały się pod okiem matki, co z kolei dobrze mogą obrazować posągi przedstawiające kobietę trzymającą na kolanach małego człowieka. Przykładem takiej diady jest statua Pepi II i jego matki, królowej Anchenesmerire II (Brooklyn Museum 39.119) ${ }^{27}$. Przedstawienia tego typu są oczywiście nawiązaniem do bogini Izydy i małego Horusa, których bardzo często przedstawiano

\footnotetext{
i Teje, wygląda jak córka pary amarneńskiej. Wytłumaczeniem jest to, że owe reliefy zostały wyrzeźbione w czasach rządów jej brata Achenatona, więc odmienny styl nie jest w tym wypadku czymś nadzwyczajnym.

${ }^{23}$ Dla księżniczek Amenhotepa III charakterystyczne są takie detale, jak kwieciste diademy, modiusy oraz długie tradycyjne suknie. Królewską Lilię w dłoni, z którą ukazywano Teje, w przypadku jej córek zastępowano sistrum, laską renepet, znakiem anch lub naszyjnikiem menat. Podczas gdy księżniczki amarneńskie ukazywane są jedynie z sistrami w dłoniach.

${ }^{24}$ Meritaton i Anchesenpaaton zostały wyniesione do ról Wielkich Matżonek Króla. Reliefy ukazujące księżniczki już jako królowe przedstawiają dorosłe kobiety. Jednak, co ciekawe i warte wzmianki, młodziutkie władczynie cały czas czerpały wiele z ikonografii swojej królewskiej matki. Porównaj: Meritaton w grobowcu Meryre II - Davies, 1905, T. 2, pl. XLI; Anchesenpaaton na złotym tronie Tutanchamona JE 62028 - http://www.griffith.ox.ac.uk/gri/carter/091.html [dostęp: 12 IX 2017].

${ }^{25}$ Dobry przykład może stanowić diada Menkaure i Chamerernebti przechowywana w Museum of Fine Arts w Bostonie MFA 11.1738, http://www.mfa.org/collections/object/king-menkaura-mycerinusand-queen-230 [dostęp: 12 IX 2017]. Widzimy faraona w sztywnej pozie oraz jego małżonkę, która obejmuje jednym ramieniem męża w pasie, a drugą dłoń trzyma na jego ramieniu. Król został ukazany, jako bardzo zimny, nieokazujący uczuć, wręcz surowy małżonek.

${ }^{26} \mathrm{~W}$ czasach rządów Amenhotepa III, czyli w przeddzień rewolucji amarneńskiej, sytuacja nadal nie uległa zmianie. Król przedstawiany był wraz z rodziną zawsze w sztywnych i formalnych pozach. Np.: Przedstawienie rodziny z grobowca Cheruefa (The Tomb of Kheruef, 1980, pl. LVII).

${ }^{27} \mathrm{https} / / /$ www.brooklynmuseum.org/opencollection/objects/3446 [dostęp: 12 IX 2017].
} 
w ten sposób ${ }^{28}$. Izyda, dzięki swoim ciężkim i przykrym przygodom opisanym w mitologii (Lipińska, Marciniak, 1977, s. 47-67), stanowiła uosobienie idealnej królowej, której jedną z głównych powinności było dbanie i wychowywanie potomstwa, ale także wspieranie męża, trwanie przy rodzinie w czasach pokoju, ale także chaosu, kiedy to władczyni powinna wykazywać się odwagą, inteligencją, sprytem i oddaniem.

Na tle nieukazujących zbyt głębokich uczuć egipskich zabytków, artefakty z Okresu Amarneńskiego odznaczają się niesamowitą uczuciowością i ciepłem przedstawień. Poniżej zostanie przedstawionych kilka szczególnych zabytków z czasów rząáów Achenatona i Nefertiti, które w bardzo wymowny sposób unaoczniają więzy rodzinne amarneńskiej familii. Co istotne, reliefy i rzeźby ukazują nie tylko królewską idyllę w Achetaton, ale również chwile pełne smutku i żałoby.

\section{Sceny rodzinne}

Znamy jedno przedstawienie, zachowane w zadowalającym stanie, które przedstawia całą rodzinę amarneńską. Jest to relief z grobowca dostojnika Meryre II (ryc. 6), który ukazuje składanie trybutu przez Syryjczyków i Nubijczyków w 12. roku panowania Achenatona, ósmego dnia drugiego miesiąca pory peret (Davies, 1905, T. 2, pl. XXXVIII, T. 3, pl. XIII). Mimo że jest to scena bardzo oficjalna ${ }^{29}$, dziewczynki ukazano bardzo zajęte sobą. Ich rodzice siedzą na tronach i odbierają honory, zaś za ich plecami w dwóch rejestrach ukazano księżniczki. Wyżej dwie najstarsze siostry, Meritaton i Maketaton, trzymają się za dłonie. Maketaton odwraca się do Anchesenpaaton i obejmuje ją w pasie drugą ręką. Niżej przedstawiono najmłodsze dziewczynki - warto zauważyć, że mają one wyraźnie krótsze loki młodości niż ich starsze siostry. Neferneferuaton-Taszerit trzyma w dłoniach niestety dziś już niedający się rozpoznać przedmiot. Za nią stoi Neferneferure, w której ramionach ukazano małe zwierzątko, najprawdopodobniej młodą gazelę. Natomiast najmłodsza księżniczka, Setepenre, ma przewieszone przez ramię naręcze kwiatów.

Innym zabytkiem, który najprawdopodobniej ukazywał rodzinę królewską w pełnym składzie, jest ledwo zachowane do dzisiejszych czasów malowidło z Domu Króla w Achetaton (Ashmolean Museum, Oxford 1893.1-41) . $^{30}$ Zachowany fragment (ryc. 7). ukazuje dwie obejmujące się księżniczki, najprawdopodobniej są to

\footnotetext{
${ }^{28}$ Np.: MMA 45.4.4, https://www.metmuseum.org/art/collection/search/545969 [dostęp: 12 IX 2017].

${ }^{29}$ Zarówno w przypadku sceny składania trybutu, jak i reliefów ukazujących zabijanie wrogów Egiptu (patrz niżej), możemy stwierdzić, że są to przedstawienia polityczne, jednak w związku z tym, że dziewczynki nie są aktywnymi bohaterkami owych scen, tylko towarzysza swoim rodzicom, którzy pełnią funkcje polityczne, taka kategoria reliefów nie zostanie wyróżniona.

${ }^{30}$ Rekonstrukcję malowidła przedstawił Norman de G. Davies w jednym ze swoich artykułów (Davies, 1921, s. 1-7, pl. II).
} 


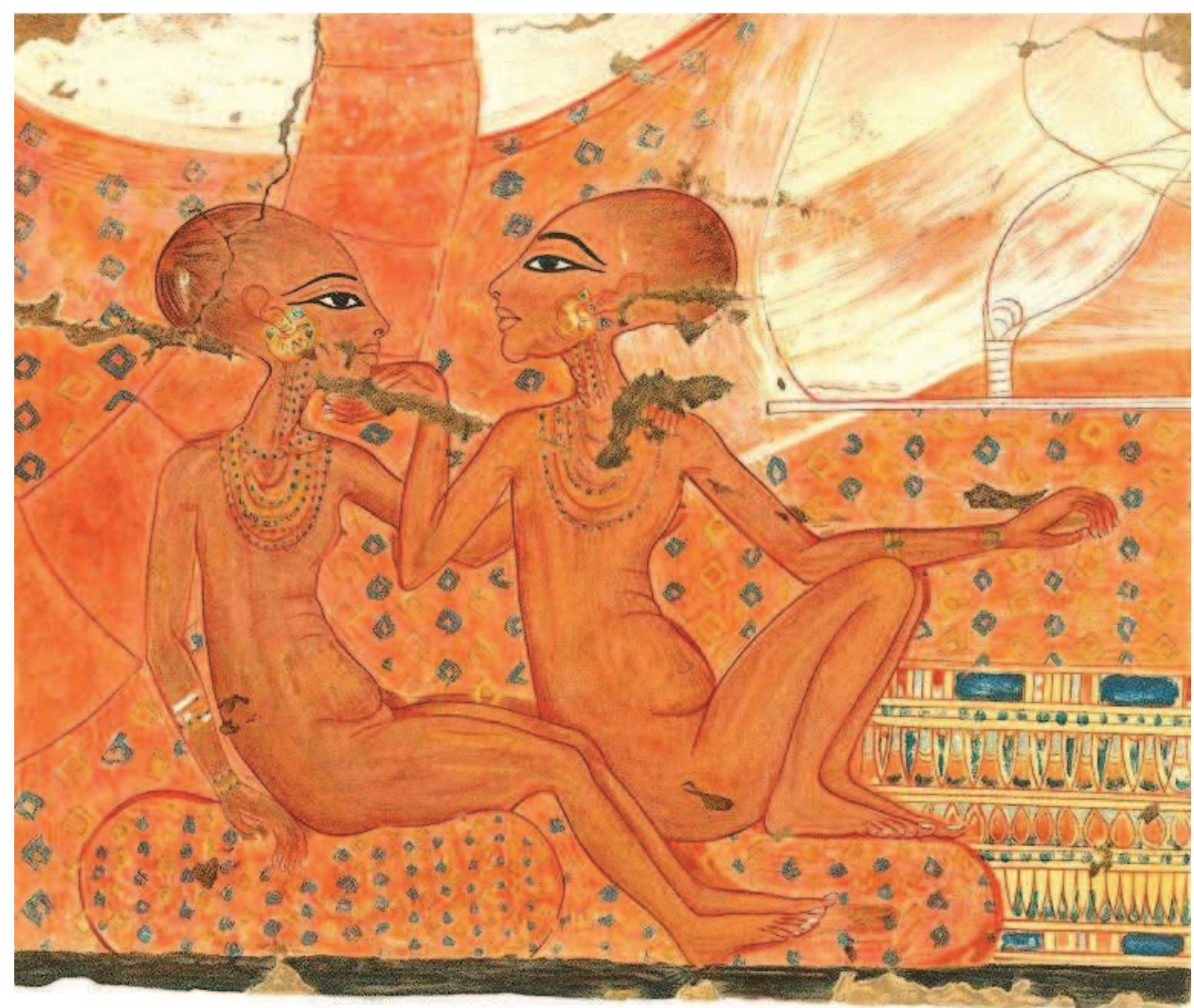

Ryc. 7. Malowidło z Domи Króla w Achetaton. Ashmolean Museum, Oxford 1893.1-41 (Davies, 1921, pl. I) Fig. 7. The painting from King's House at Akhetaten. Ashmolean Museum, Oxford 1893.1-41 (Davies, 1921, pl. I)

młodsze siostry siedzące na poduszkach. Jedna odwraca się ku drugiej i gładzi ją po podbródku. Dziewczynki są nagie, choć noszą biżuterię - bogate naszyjniki, kolczyki i bransolety. Mimo bardzo dużych uszkodzeń możemy dostrzec za nimi pozostałości większej postaci, która również odpoczywa na poduszce. Księżniczki to zapewne Neferneferuaton-Taszerit i Neferneferure, które towarzyszą swojej matce Nefertiti. Naprzeciwko władczyni widoczne są trzy pary małych nóg oraz większe stopy w sandałach, które należą do siedzącego na prostym stołku Achenatona. Przed królem stoją trzy najstarsze księżniczki: Meritaton, Maketaton i Anchesenpaaton (Davies, 1921, s. 2-4). Setepenre, być może niedawno narodzoną, Nefertiti trzyma w ramionach - możemy stwierdzić to dzięki, do niedawna zachowanej, małej rączce dziewczynki (Petrie, 1931, s. 138-139).

Bardzo znanymi przedstawieniami amarneńskiej rodziny są małe stele, które ustawiano na domowych ołtarzach w Achetaton. Na dwóch, dość do siebie podob- 
nych stelach $\ddot{A M} 14145^{31}$ oraz JE $44865^{32}$ uwieczniono rodziców wraz z dziewczynkami. Obie stele datowane są na wczesny okres rządów Achenatona ${ }^{33}$.

Pierwsza ze stel (ÄM 14145) została już pokrótce opisana wyżej. Achenaton podnosi $w$ ramionach Meritaton, aby ją pocałować. Na kolanach Nefertiti siedzi Maketaton, podczas gdy Anchesenpaaton wspina się po matczynym ramieniu i gładzi rączką jej policzek. Nad amarneńską rodziną świeci Aton, który podsuwa pod nosy małżonków znaki życia, anch. Księżniczki są nagie, a lok młodości widoczny jest tylko na głowie Maketaton, która odwraca się twarzą do matki.

Drugi zabytek, JE 44865, przedstawia bardzo podobną scenę. Stojąca przed ojcem Meritaton otrzymuje od niego kolczyki. Na kolanach zapewne lubiącego rozpieszczać swoje pociechy ojca spoczywają kolejne prezenty w postaci złotych naszyjników. Nefertiti towarzyszą dwie - na ten moment - najmłodsze córki. Maketaton stoi na matczynych kolanach, a obok grzecznie siedzi Anchesenpaaton. Maketaton czule gładzi mamę po podbródku. Nefertiti jedną dłonią asekuruje stojącą dziewczynkę, a drugą gładzi po głowie. Księżniczki tak jak na poprzedniej steli zostały ukazane bez szat. Meritaton i Anchesenpaaton mają widoczny na głowach lok młodości. Warto zaznaczyć, że na obu stelach, mimo pełnych regaliów, w jakich przedstawiono parę królewską, Achenaton i Nefertiti siedzą na bardzo prostych stołkach, co sprawia, że reliefy nie są aż tak formalne i oficjalne.

Kolejny wart przedstawienia zabytek jest bardzo wyjątkowy i niestety nie dotrwał do naszych czasów w całości. Fragment steli przechowywanej w muzeum w Luwrze (E11624) ${ }^{34}$, ukazuje siedzącego na tronie Achenatona - a właściwie nogi władcy, na których siedzi Nefertiti - widoczne są wyłącznie nogi i część tułowia królowej. Na kolanach władczyni przedstawiono dwie pary małych stópek oraz, na wysokości biustu i tali, rączkę, którą jedna z księżniczek zapewne opiera się o matczyne ramię. Zabytek, mimo dużego uszkodzenia, jest jednym z najpiękniejszych artefaktów Okresu Amarneńskiego. Scena zaprezentowana na reliefie kłóci się z dotychczas chłodnym i bardzo formalnym kanonem przedstawień rodziny królewskiej. Achenaton i Nefertiti nie dość, że bawią się ze swoimi pociechami, to jeszcze zostali ukazani w dość intymnej pozie, ponieważ faraon trzyma na kolanach swoją małżonkę. Ukazanie tak bliskich, choć naturalnych relacji było dotychczas, jak i w późniejszych okresach nie do przyjęcia. Możemy się jedynie domyślać, jak pięknie musiała prezentować się owa stela przed zniszczeniem.

\footnotetext{
${ }^{31}$ Patrz: http://www.smb-digital.de/eMuseumPlus?service=direct/1/ResultLightboxView/result.t1.col lection_lightbox.\$TspTitleImageLink.link\&sp=10\&sp=Scollection\&sp=SfieldValue\&sp=0\&sp=0\&sp= $3 \& \mathrm{sp}=$ Slightbox_3x4\&sp=0\&sp=Sdetail\&sp=0\&sp=F\&sp=T\&sp=1 [dostęp: 12 IX 2017].

${ }^{32}$ Patrz: http://www.globalegyptianmuseum.org/record.aspx?id=15416 [dostęp: 12 IX 2017].

${ }^{33}$ Datacja jest możliwa dzięki zapisanej na stelach starszej wersji imienia Atona: ${ }^{\Upsilon} n h-R^{\top}-h r-3 h t y-$ hִi-m-3ht-imy-rn-f-šw-nty-m-Itn, czyli Niech żyje Re-Horachty radujacy się na horyzoncie o imieniu Szu, który jest pod postacia Atona.

${ }^{34}$ Patrz: http://cartelen.louvre.fr/cartelen/visite?srv=car_not_frame\&idNotice=14649 [dostęp: 12 IX 2017].
} 
Na jednej ze wspomnianych stel uchwycono Achenatona podczas składania pocałunku Meritaton. Jednak warto zaznaczyć, że również Nefertiti ukazywano w podobnej konwencji. Na talatat z Hermopolis (Brooklyn Museum 60.197.8) ${ }^{35}$ ukazano władczynię całującą jedną ze swoich córeczek.

Wartym wspomnienia zabytkiem przedstawiającym rodzinę amarneńską jest również nieukończona płytka $\mathrm{z}$ karneolu przechowywana w Fitzwilliam Museum w Cambridge (4606.1943) ${ }^{36}$. Zabytek przedstawia Achenatona całującego Nefertiti $^{37}$. Para królewska jednocześnie tuli do siebie dwie księżniczki, być może najstarsze, czyli Meritaton i Maketaton.

W sztuce Okresu Amarneńskiego pojawiają się tak zwane sceny bankietów, co istotne, ten sam rodzaj scen został ukazany w odmienny sposób w Karnaku i w Achetaton. Otóż sceny z Karnaku charakteryzują się sztywnością i są bardzo formaln ${ }^{38}$, nie ma w nich miejsca na dziecięce igraszki i zabawy. Na talatat para królewska siedzi samotnie przy suto zastawionym stole. Achenaton i Nefertiti nie piją napojów ani nie spożywają posiłków, ubrani są w pełne regalia. Prawdopodobnie są to sceny z bankietu, który odbył się z okazji heb-sed faraona.

Zupełnie inaczej prezentują się sceny z Amarny ${ }^{39}$, gdzie rodzina została ukazana podczas wspólnie spędzanego czasu. Dwie najlepiej zachowane sceny bankietu znajdują się w grobowcu Hui. W uczcie biorą udział amarneńskie księżniczki, ich rodzice oraz babka Teje, której towarzyszy najmłodsza córa Baketaton. Dziewczynki mają na głowach lok młodości, na jednym reliefie przedstawione są nagie (Davies, 1905, T. 3, pl. IV), a na drugim ubrane są w klasyczne amarneńskie szaty (Davies, 1905, T. 3., pl. VI ). Księżniczki towarzyszą Nefertiti. Na jednej ze scen na małych krzesełkach tuż przy matce siedzi Meritaton wraz z jedną z sióstra ${ }^{40}$, zaś na drugim reliefie Anchesenpaaton stoi na podnóżku, opierając się o nogi swojej mamy i trzymając jedną rękę na tronie, obok którego ukazano drugą księżniczkę ${ }^{41}$. Reliefy są bardzo bogate, każdy członek rodziny pije lub je, a obok niego wznosi się suto zastawiony stół.

Sceny bankietów znajdują się również w grobowcach Pentu (Davies, 1906, T. 4, pl. X) oraz Jahmesa (Davies, 1905, T. 3, pl. XXXIV), jednak nie dotrwały one do naszych czasów w zbyt dobrym stanie zachowania. Na widocznych fragmentach

\footnotetext{
${ }^{35}$ Patrz: https://www.brooklynmuseum.org/opencollection/objects/3700 [dostęp: 12 IX 2017].

${ }^{36}$ Patrz: http://data.fitzmuseum.cam.ac.uk/id/object/59058 [dostep: 12 IX 2017].

${ }^{37}$ Identyfikację postaci można przeprowadzić dzięki nakryciom głów. Otóż Achenaton ma na głowie Koronę Cheperesz, zaś Nefertiti najprawdopodobniej tzw. Królewski Czepek.

${ }^{38}$ Np.: Redford, 1976, pl. LXX, LXIII, LXVI.

${ }^{39}$ Np.: Davies, 1905, T. 3, pl. IV, VI.

${ }^{40}$ Imię drugiej księżniczki jest tak zniszczone, że niemożliwe jest jego odczytanie. Patrz: Davies, 1905, T. 3, pl. IV.

${ }^{41}$ Najprawdopodobniej jest to Meritaton, aczkolwiek podobnie jak na poprzednim reliefie, imię nie przetrwało w zbyt dobrym stanie. Patrz: Davies, 1905, T. 3, pl. VI.
} 
z grobowca Jahmesa dostrzec można tronujących Achenaton i Nefertiti, której tak jak poprzednio towarzyszą księżniczki. Dwie dziewczynki siedzą na stołeczkach tuż przy nogach władczyni, a trzecią ukazano na kolanach matki.

\section{Sceny zabijania wrogów Egiptu}

Jak się okazuje, księżniczki, a przynajmniej jedna z nich, najprawdopodobniej Meritaton, ukazana została w scenach zabijania wrogów Egiptu. Reliefy tego typu są jednymi z najstarszych wchodzących do kanonu przedstawien faraonów, którzy, uśmiercając jeńców, panowali nad chaosem - isefet, jednocześnie wprowadzając równowagę, ład, porządek i harmonię, czyli maat. Zarówno Achenaton ${ }^{42}$, jak i Nefertiti ${ }^{43}$ zostali uwiecznieni $w$ charakterystycznej pozie $z$ mieczem lub maczugą w jednej dłoni i jeńcem trzymanym za włosy w drugiej.

Na niektórych reliefach faraonowi towarzyszy małżonka, jednak znane są również takie przypadki, kiedy Achenatona ukazano razem z królowa i księżniczką. Taką sytuację przedstawia talatat z Hermopolis (MMA 1985.328.15) ${ }^{44}$. Na bloku ukazano królewską łódź przycumowaną do wschodniego brzegu Nilu nieopodal pałacu (Cooney, 1965, s. 80). Uwagę zwraca kiosk, nad którym promienieje Aton. Wewnątrz ukazano Achenatona, stojącą za nim Nefertiti oraz księżniczkę, być może najstarszą, Meritaton. Naprzeciw pary królewskiej stoi jeniec, którego Achenaton trzyma za włosy jedną ręką, zaś drugą zamachuje się na niego mieczem chepesz lub maczugą. Nefertiti najprawdopodobniej również trzyma coś w jednej z dłoni, jednak przedstawienie jest na tyle niewyraźne, że nie da się tego jednoznacznie określić. Za królową ukazano maleńką postać królewskiej córki, która przygląda się zmaganiom rodziców. Niestety, relief jest na tyle niewyraźny, że nie jesteśmy w stanie ocenić, czy dziewczynka ma na sobie szatę, czy została przedstawiona naga.

Również w grobowcu Meryneit najwyższego kapłana Atona, który pełnił swój urząd za rządów Achenatona (Ertman, 2006, s. 62), ukazano księżniczkę wraz z ojcem. Na reliefie (Ertman, 2006, s. 63) przedstawiono również królewską barkę z dwoma kioskami. W jednym z nich widoczny jest faraon - a właściwie jego wzniesione prawe ramię, nogi oraz lewa ręka, którą król trzyma za włosy jeńca. Za Achenatonem stoi mała, naga postać, która przygląda się wydarzeniu. Możemy przyjąć, że na pewno nie jest to Nefertiti, ponieważ władczyni nigdy nie była przedstawiana w tak małej skali, dodatkowo zawsze towarzyszą jej charakterystyczne

\footnotetext{
${ }^{42}$ Np. talatat nr 3198 i 0202 05114; więcej na ten temat: Ertman, 2006, s. 59-65.

${ }^{43}$ Np. talatat z Karnaku nr 1689-2 044904104 lub z Hermopolis MFA 64.521 i 63.260; patrz: Redford, Smith 1976, pl. XXIII: 2, http://www.mfa.org/collections/object/talatat-river-scene-with-royal-bar ges-and-tow-boats-46198 [dostęp: 12 IX 2017].

${ }^{44}$ Patrz: Cooney, 1965, s. 80-88, pl. L; http://www.metmuseum.org/art/collection/search/544682 [dostep: 26 V 2017].
} 
stroje oraz nakrycia głowy. Wywnioskować można, że mała postać to towarzysząca ojcu Meritaton. Relief jest być może jednym z najstarszych przedstawień, na którym wojującemu faraonowi towarzyszy córka ${ }^{45}$.

\section{Sceny żałoby}

Tak jak już zostało wspomniane, reliefy amarneńskie ukazują nie tylko chwile pełne radości i szczęścia, ale także żałobę i smutek. Kres idylli następuje w 12. roku panowania Achenatona. W tym czasie z kart historii znikają Maketaton, Teje, Kija, Neferneferuaton Taszerit, Neferneferure i mała Setepenre. Zgony najprawdopodobniej były żniwem plagi panującej na Bliskim Wschodzie, która do Egiptu została przywleczona przez Syryjczyków podczas składania trybutu w roku 12. Śmierć Maketaton i $\mathrm{Kiji}^{46}$ zostały uwiecznione na ścianach Grobowca Królewskiego w Achetaton. Są to jedyne tego typu przedstawienia w całej ikonografii egipskiej. Reliefy cechuje bardzo duża intymność.

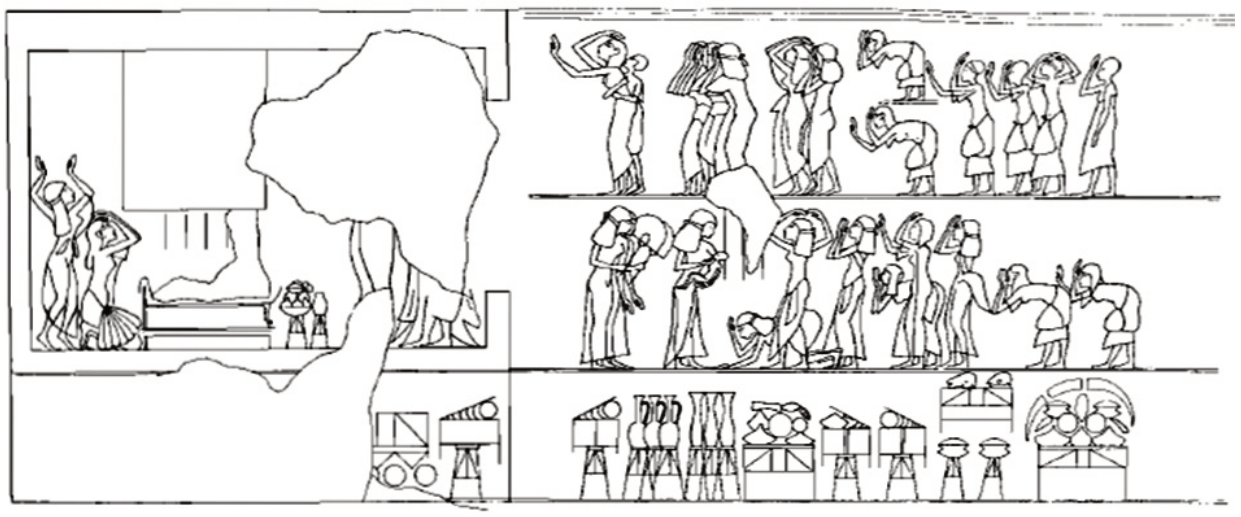

Ryc. 8. Relief z Komnaty Gamma, ściana A. Grobowiec Królewski. Amarna (Martin, 1974, ryc. 8)

Fig. 8. The relief from Gamma Chamber, wall A. The Royal Tomb. Amarna (Martin, 1974, fig. 8)

W Komnacie Gamma na ścianach A (ryc. 8; Martin, 1974, pl. LXIII, s. 42-45) i B (ryc. 9; Martin, 1974, pl. LXVIII, s. 45-48) ukazano śmierć Maketaton. Księżniczkę zapewne również pochowano w owej Komnacie (Martin, 1974, s. 38). Reliefy ukazują najbardziej wzruszające sceny z czasów rządów Achenatona i Nefertiti - lament

${ }^{45}$ Przedstawienie datowane jest na 5. rok panowania Achenatona. Do takiego wniosku doszedł E. L. Ertman w porozumieniu z M. Raven'em (Ertman, 2006, s. 64).

${ }^{46}$ Jeżeli rzeczywiście są to przedstawienia ukazujące śmierć Kiji - patrz niżej. 
pogrążonych w smutku i rozpaczy rodziców nad zmarłą córką. Możemy być pewni co do tego, że jest to Maketaton, ponieważ na obu ścianach zachowały się hieroglify $\mathrm{z}$ tytulaturą księżniczki ${ }^{47}$ nazwanej: s3.t nswt h̆t.f mrt.f $M^{\Upsilon} k$.t itn ms.t $n$ hrm.t nswt wr.t (Nfr-nfr.w-jtn nfr.t-jj.tj)| - Córka Króla z Jego Ciata, Jego Ukochana, Maketaton, Zrodzona z Wielkiej Matżonki Króla (Neferneferuaton-Nefertiti)|.

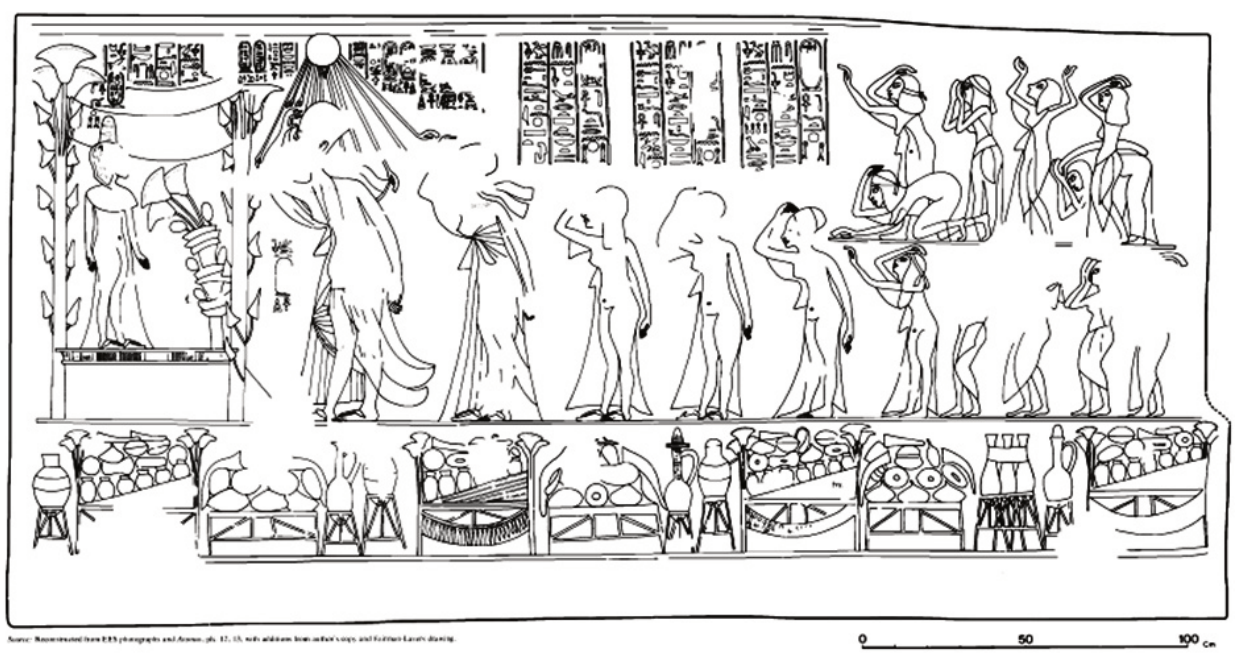

Ryc. 9. Relief z Komnaty Gamma, ściana B. Grobowiec Królewski. Amarna (Martin, 1974, ryc. 11)

Fig. 9. The relief from Gamma Chamber, wall B. The Royal Tomb. Amarna (Martin, 1974, fig. 11)

Na ścianie A (ryc. 8) widoczne są mary, na których zapewne spoczywało ciało zmarłej Maketaton. Tuż obok ukazano Nefertiti i Achenaton, niestety relief w górnej części jest bardzo uszkodzony, więc możemy się jedynie domyślać, że para królewska została zaprezentowana w podobnych pozach co w Komnacie Alfa na ścianie F (ryc. 10), co zostanie opisane poniżej. W drugiej części reliefu ukazano opiekunkę tulącą w objęciach noworodka. Rozpostarty nad dzieckiem wachlarz bht, czyli symbol królewskości, sugeruje, że jest to księżniczka lub książę. Wiele faktów może wskazywać na to, że jest to mały Tutanchaton, którego mamą jest Nefertiti ${ }^{48}$.

Na drugim reliefie z Komnaty Gamma, ściana B (ryc. 9), ukazano kolejną scenę żałoby. Maketaton, lub jej posąg, stoi w altanie o papirusowych kolumnach. Dziewczynka ubrana jest w charakterystyczną dla jej matki suknię, a jej główkę zdobi lok

${ }^{47}$ Pełna tytulatura zachowała się na ścianie B.

${ }^{48}$ Taką hipotezę wysunął M. Gabolde już w 1993 roku (Gabolde, 1993, s. 29-34; Gabolde, 1998.; Gabolde, 2002, s. 32-48; Gabolde, 2013, s. 177-203). Jak już zostało wspomniane we wstępie, kwestia rodziców młodego faraona nie będzie poruszana w tej pracy. 
młodości, nad którym usytuowano stożek pachnideł. Przed księżniczką, w geście żałoby, wznosząc ku twarzom jedną z dłoni, stoją Achenaton, Nefertiti, Meritaton, Anchesenpaaton i Neferneferuaton. Księżniczki kolejny raz wyglądają jak małe kopie swojej matki. Brak najmłodszych księżniczek, Neferneferure i Setepenre, może oznaczać, że również i one mogły już nie żyć w momencie śmierci Maketaton.

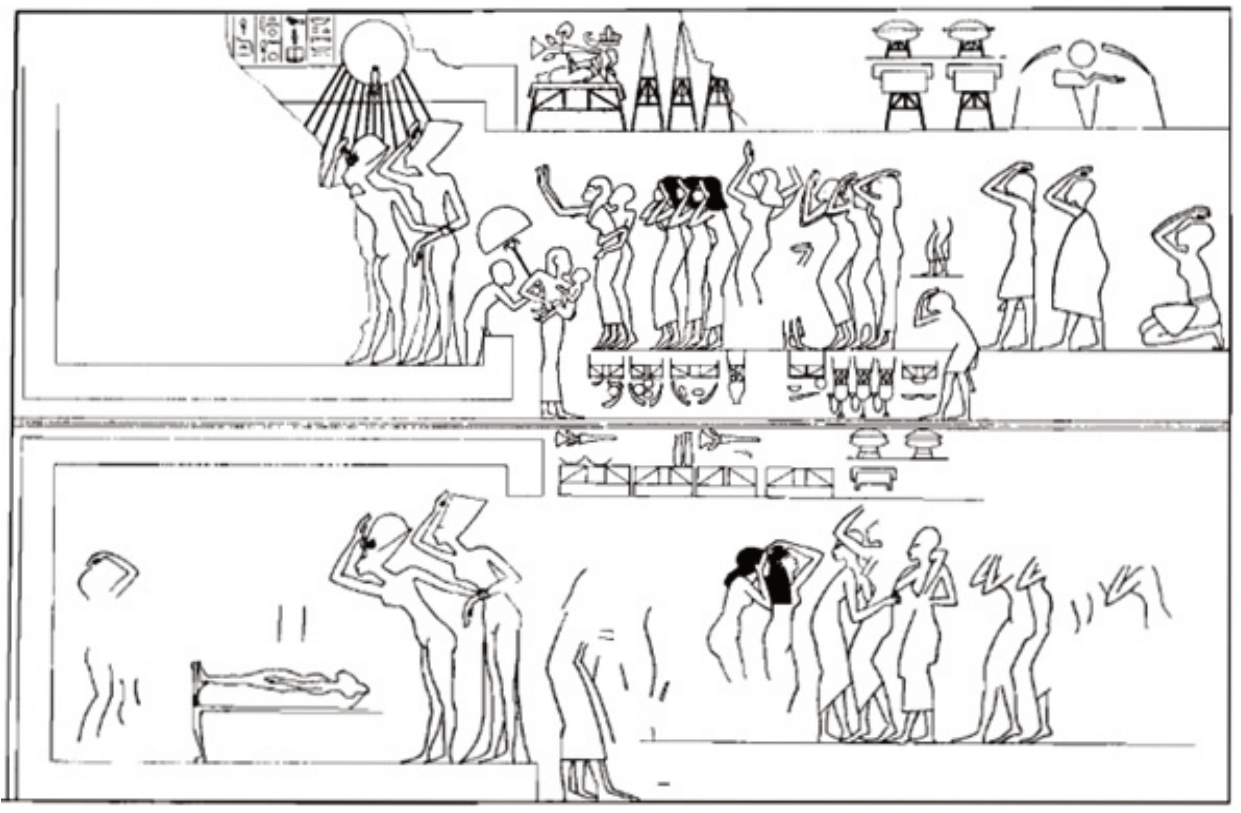

Ryc. 10. Relief z Komnaty Alfa, ściana F. Grobowiec Królewski. Amarna (Martin, 1974, ryc. 7)

Fig. 10. The relief from Alfa Chamber, wall F. The Royal Tomb. Amarna (Martin, 1974, fig. 7)

W Komnacie Alfa, na ścianie F (ryc. 10), uwieczniono kolejną scenę żałoby podzieloną na dwa rejestry. Niestety w górnej części przedstawienia relief został bardzo uszkodzony i postać osoby zmarłej jest zupełnie niewidoczna. Zachowały się jednak sylwetki stojących przed nią Achenatona oraz Nefertiti. Para królewska wznosi ręce ku twarzom. Achenaton, w geście głębokiego współczucia, trzyma za nadgarstek małżonkę. Za drzwiami komnaty, w której ukazano parę królewską, stoi niania trzymająca $w$ ramionach niemowlę. Nad dzieckiem również tym razem rozpostarty jest królewski wachlarz. Za opiekunką przedstawiono zawodzące płaczki. Dolny rejestr zachował się w znacznie lepszym stanie. Na marach leży ciało kobiety. Achenatona i Nefertiti ukazano w identycznych pozach co wyżej. Tym razem obecne są wyłącznie rozpaczające płaczki oraz omdlewająca kobieta - brak opiekunki 
z dzieckiem na ręku. Kto został złożony na marach? Do dziś nie możemy mieć pewności, czy to kolejne przedstawienie żałoby po śmierci Maketaton, czy może po śmierci Kiji ${ }^{49}$. Jedno jest pewne, sposób, w jaki ukazano rodzinę amarneńską podczas żałoby, przedstawia intymność tychże chwil i wielki ból, jaki musieli przeżywać zarówno rodzice, jak i księżniczki po stracie bliskiej im osoby. Gesty oraz pozy, w jakich ukazano żałobników, ukazują wielkość tragedii, jaka spotkała dotychczas szczęśliwą rodzinę królewską cieszącą się łaskawościami boga Atona.

\section{PODSUMOWANIE}

Dzięki przedstawieniom córek Achenatona i Nefertiti ikonografia amarneńska nabrała zupełnie innego wydźwięku niż dotychczasowe, bardzo oficjalne przedstawienia rodzin królewskich. Miłość i emocje ukazane w sztuce między siostrami oraz między rodzicami a ich dziećmi są widoczne jak nigdy we wcześniejszych, jak i późniejszych okresach. Niezależnie od rodzaju reliefów, czy to rodzinna sielanka, czy sceny pełne smutku, biją z nich silne emocje i wsparcie, jakie dawali sobie członkowie rodziny królewskiej.

Kanon przedstawień księżniczek amarneńskich jest bardzo specyficzny. Oczywiście dziewczynki nie mogły nosić na głowach królewskich koron, aczkolwiek zwiewna, otwarta z przodu, plisowana szata Nefertiti jak najbardziej mogła stać się charakterystycznym detalem dla jej sześciu córeczek. Siostry ukazywano zawsze jako małe dzieci, a nie dorosłe kobiety jak ich ciotki. Fakt ten dobrze thumaczy brak ureuszy na ich główkach, które z kolei pojawiły się u sióstr Achenatona przedstawianych jako dorosłe dziewczęta.

Kanon przedstawień amarneńskich księżniczek bez wątpienia nawiązuje do stylu ikonograficznego ich matki. Dziewczynki, niezależnie od wieku, miały stanowić małe kopie Nefertiti - czy to w szatach, czy bez nich siostry mają tę samą figurę co ich rodzicielka. Księżniczki występują w różnych typach scen, zarówno w tych ukazujących rodzinę wspólnie spędzającą czas, jak i opłakującą śmierć bliskiej im osoby. Są również ukazywane jako obserwatorki bardziej oficjalnych wydarzeń, takich jak składanie trybutu. Natomiast Meritaton, jako najstarsza córka, pełni także ważną funkcję podczas składania ofiar Atonowi przez jej matkę oraz jest obecna w scenach, gdzie jej ojciec walczy z chaosem ukazanym pod postacią jeńca wojennego.

\footnotetext{
${ }^{49}$ Geoffrey Martin zasugerował, że niemożliwe jest, aby w dwóch miejscach w tym samym grobowcu przedstawiono to samo wydarzenie, czyli śmierć Maketaton. W związku z tym stwierdził, że jest to być może scena ukazująca śmierć Kiji, która zmarła, rodząc dziecko (Martin, 1974, s. 39-40). Ojcem księcia lub księżniczki miałby być sam Achenaton. Za hipotezą G. Martina opowiada się wielu badaczy, jak na przykład J. Van Dijk (Van Dijk, 2006, s. 83-88), Nicholas Reeves (Reeves, 2001, s. 128-129) czy Joyce Tyldesley (Tyldesley, 2003, s. 175-176).
} 
Jaki mógł być powód, dla którego amarneńskie księżniczki stały się tak często pojawiającymi się na reliefach postaciami? Czemu służyło afiszowanie się pary królewskiej z córeczkami? Otóż, jak już zostało wspomniane, Achenaton i Nefertiti, jako mityczne bliźnięta ${ }^{50}$ Szu i Tefnut, dali życie sześciu córkom: Meritaton, Maketaton, Anchesenpaaton, Neferneferuaton, Neferneferure oraz Setepenre. Dziewczynki miały być widocznym owocem miłości pary królewskiej. Wydaje się zatem, że tak intensywne przedstawianie księżniczek w ikonografii możemy wytłumaczyć kwestiami religijnymi. Aczkolwiek, z innej strony, ze względu na drastyczne zmiany, jakie wprowadził Achenaton w egipskiej religii, król mógł wykorzystać wizerunki dzieci do ocieplenia zarówno swojego wizerunku - dyktatora i heretyka (?) - jak i Nefertiti. Patrząc z perspektywy człowieka XX i XXI wieku, moglibyśmy porównać przedstawienia szczęśliwej rodziny amarneńskiej do chociażby fotografii ukazujących Führera z jego ukochanym owczarkiem niemieckim Blondi lub do plakatów propagandowych przedstawiających Stalina z gromadką dzieci. Jednak nie należy spoglądać na starożytny Egipt przez pryzmat współczesności, ponieważ dla Egipcjan wiele aspektów się ze sobą splatało, a granice między sacrum a profanum często się zacierały, zaś mentalność starożytnych w niektórych aspektach mogła znacznie różnić się od naszej. Wydaje się zatem, że przedstawienia księżniczek z jednej strony rzeczywiście mogą być podyktowane potrzebami religijnymi, jednak z drugiej strony nic nie świadczy przeciw temu, że obrazy ukazują prawdziwe uczucia i emocje rodziny królewskiej z Achetaton.

\section{BIBLIOGRAFIA}

Aldred C.

1978 Jewels of the Pharaohs: Egyptian Jewelry of the Dynastic Period. Nowy York: Ballantine Books.

Allen J. P.

2009 The Amarna Succession. W: P. J. Brand, L. Cooper (red.), Cousing his name to live: Studies in Egyption epigraphy and history in memory of William J. Muarnane (s. 9-20). Linden/Bosfor: Brill.

Cooney J. D.

1965 Amarna Reliefs from Hermopolis in American Collections. New York: Brooklyn Museum.

Davies N. G.

1921 Mural Paintings in the city of Akhenaten. Journal of Egyptian Archaeology, 7, s. 1-7.

Davies N. G.

1903-1908 The Rock Tombs of Amarna (T. 1-6). London.

Davies N. G., Mapsero G., Newberry P. E.

1907 The Tomb of Iouiya and Touiyou. London.

${ }^{50}$ Być może ze względu na tę ideę para królewska w pewnym momencie była przedstawiana jako bardzo podobne do siebie postacie - bliźnięta. 
Feucht E.

2001 Childhood. W: D. B. Redford (red.), The Oxford Encyclopedia of Ancient Egypt (T. 1, s. 261-264). Oxford - New York.

Gabolde M.

1993 La postérité d'Aménophis III. Égyptes, 1, marzec, s. 29-34. Avignon.

1998 D'Akhenaton à Toutânkhamon. Lyon - Paris (= Collection de l'Institut d'Archéologie et d'Histoire de l'Antiquité, Université Lumière Lyon 2, T. 3).

2002 La parenté de Toutânkhamon. Bulletin de la Société Française d'Egyptologie, 155, październik, s. 32-48.

2013 L'ADN de la famille royale amarnienne et les sources égyptiennes. Égypte nilotique et méditerranéenne, 6, s. 177-203.

Gardiner A. H.

1957 Egyptian Grammar. Being an Introduction to the Study of Hieroglyphs. Oxford: Griffith Institute, Ashmolean Museum.

Guillemette A.

2012 Życie codzienne. Egipt w czasach piramid. Warszawa: Świat Książki.

Hawass Z. i in.

2010 Ancestry and Pathology in Tutankhamun's Family. Journal of American Medical Association, 303(7), s. 638-647.

Ikram S.

2003 Śmierć i pogrzeb w starożytnym Egipcie. Warszawa: Państwowy Instytut Wydawniczy

Kemp B. J.

2013 The city of Akhenafen and Nefertiti: Amarna and its people. London: Thames \& Hudson. Lipińska J., Marciniak M.

1980 Mitologia starożytnego Egiptu. Warszawa: Wydawnictwo Artystyczne i Filmowe.

Martin G. T.

1974 The Royal Tomb at El-Amarna. The Reliefs. Inscriptions, and Architecture (T. 2). London: Egypt Exploration Society.

Petrie W. M. F.

1931 Seventy Years in Archaeology. London: S. Low, Marston \& Co.

Reeves N.

2001 Akhenaten: Egypt's False Prophet. London: Thames and Hudson.

Rachet G.

1995 Dziecko. W: Stownik cywilizacji egipskiej. Katowice, s. 92.

Redford D. B.

1987 Akhenaten - the heretic king. New Jersey: Princeton University Press.

Redford D. B., Smith R. W.

1976 The Akhenaten Temple Project, Initial Discoveries, T. 1: The Tomb of Kheruef. Warminster: Aris and Phillips.

1980 Theban Tomb 192 by the epigraphic survey in cooperation with The Department of Antiquities of Egypt. Chicago: The Oriental Institute.

Tyldesley J.

2003 Nefertiti. Stoneczna królowa Egiptu. Warszawa: Państwowy Instytut Wydawniczy. 
Van Dijk J.

2006 The Death of Meketaten. W: Causing His Name to Live: Studies in Egyptian Epigramartinphy and History in Memory of William J. Murnane (s. 83-88). Memphis.

\title{
THE INFANT ICONOGRAPHY OF AMARNA PERIOD PRINCESSES
}

\author{
S u m m a r y
}

The main aim of the article is the analysis of representations of Akhenaten and Nefertiti's daughters in Amarna art. The princesses' style is highly characteristic and deviates significantly from the formal and stiff cannon of the royal family representation from another period in ancient Egypt.

Artefacts showing the life of the family from Akhetaten are ones from the most beautiful pictures in ancient Egypt representing children and their parents together. Monuments are showing family's love in a direct, literal way.

The first part of the work shows the hieroglyphs (in different variants) which were used for children in ancient times. The signs represent the way in which the infants have been portrayed in Egyptian iconography - naked, with a finger in their mouths and which the side lock of youth on the head. Girls as well as boys were shown without robes, but often wearing jewellery. It seems that it was the only artistic cannon thanks to which adults and infants could be distinguished.

The next part of the work focuses on the details of Amarna princesses representations. The analysis involves clothing and headdressing. At first, in order to emphasise the uniqueness of the Amarna children iconography, the children's art canon has been shown which was obtained at the reign of the Akhenaten's father Amenhotep III. The daughters of Amenhotep III and Tiye (Satamon, Henuttaneb, Aset and Nebetah - without the youngest sister, Baketeten, because she was showed in typical style for Amarna princesses) were never represented as small and naked children with the side lock of youth on the heads, but as young girls/maidens. Whereas sisters from Amarna were showed as the small copies of their mother, or as small and naked children.

The royal daughters are often shown naked or in robes looking like delicate tied with sash in waist or under bust dress belonging to their mother Nefertiti. Though girls - regardless of age have always been portrayed with the side lock of youth. Royal daughters often look identically like their mother. Only the head dressing seems different or lack of it because princesses were shown with a side lock of youth, while the queen recently was shown with her Blue Crown.

The earliest representations come from Karnak, and the most often shown daughter is the eldest one - Meritaten. The girl had played highly significant role on the royal court since the earliest years. Meritaten has been shown the closest to her father or standing close behind the parents which bears testimony of her high position as the eldest daughter.

On the pylon reconstructions from Hut-Benben and Nefertiti's Colonnade Meritaten was perpetuated in the typical way for The Great King's Wife which assists pharaoh-priest during a religious ceremony, except that the priest's role belongs to Nefertiti. The princess was shown with the side lock of youth on the head and in a dress looking identically as her mother's. These earliest images of Meritaten are reflecting the main cannon of princesses' representations which appear at 
Karnak. After the transfer to the new capitol, Akhetaten, the girls have still been shown in dresses looking like their mother's or naked.

There exists only one picture showing Amarna princess in a short dress (referring to representations of the Akhenaten's sisters - the aunts of the Amarna princesses). This picture has been discovered on the lid of the box from Tutankhamun's tomb. The representation belongs to little Neferura dresses in kilt. The girl has also a side lock on her head.

The highly crucial element of the princesses' iconography is the hairdo. It is significant to indicate that the side lock of youth can have different forms. Girls can have it on their heads a classic side lock, or its modified version called nubian side lock as it resembles the part of this wig.

While analysing iconographic details characteristic for Amarna princesses, we can see the enormous influence of their mother's representation cannon. Akhenaten's sisters are also worth mentioning as they were represented in analogical way to their mother Tiye.

The next part of the article shows the variety of the scenes in which princesses were represented. It is highly essential that before and after Amarna Period the relations between royal family members were pictured with the huge circumspection. As well as the royal couple and their children, they have been shown in a formal and stiff way. Whereas artefacts from Amarna Period are evoking tender emotions.

The girls have been shown not only in family scenes enjoying a good time with their parents, but also accompanying the royal couple in scenes of tribute from Nubia and Syria, in the scenes of killing enemies of Egypt and in the heart-touching mourning scenes. We can see the royal family resting calmly in the palace on the painting from King's House at Akhetaten (Ashmolean Museum, Oxford 1893.1-41) but also on a lot of stelas (e.g.: ÄM 14145, JE 44865, Louvre E11624).

The family has been shown on so-called banquet scenes where the princesses and the royal couple are assisted by Tiye and Baketaten.

Meritaten has been also represented in the scenes of killing Egytp's enemies. On a few reliefs Akhenaten has been shown together with Nefertiti. However, there are known also pictures where pharaoh is accompanied by the queen and their eldest daughter, e.g. talatat from Hermopolis (MMA 1985.328.15) or a relief from the tomb of the high priest Meryneith.

The girls have been shown also in mourning scenes. The death of Maketaten and Kiya (?) has been depicted on the wall of the Royal Tomb in Akhetaten. These are the only representations of this type in all ancient Egyptian iconography. Reliefs featured by high intimacy. Meritaten, Ankhesenpaaten and Neferneferuaten have been shown in similar way like their parents - in the mourning gesture with one hand rising up to the face. In some of them however the princesses look likes little copies of their mother. The gestures and poses of the mourners represent the hugeness of tragedy which meets so far fortunate royal family.

To summarize, love and emotions depicted in the Amarna art between sisters and another family members are visible like never before and after Amarna Period. The representations of the six daughters of Akhenaten and Nefertiti - Meritaten, Maketaten, Ankhesenpaaten, Neferneferuaten, Neferneferure and Setepenre - besides being the confirmation of the spouses' fertility, also performed an important religious function - the girls together with their parents and the god Aten created the divine Ennead just like the model of the nine gods from Heliopolis.

The intensive princesses representations in iconography might be explained by religious issues, however, on the other hand, because of the serious changes issued by Akhenaten in Egyptian religion the king might have been simply using children's representations in order to thaw his own image (the dictator and heretic) - so as Nefertiti. 